\title{
ANALISIS WAKTU TUNGGU DAN WAKTU PELAYANAN PENDAFTARAN DI RUMAH SAKIT UMUM DAERAH KOTA BANDUNG TAHUN 2019
}

\author{
Weni Tusrini $^{*}$, Elsa Pudji Setiawati², Dani Ferdian², Sharon Gondodiputro², Guswan Wiwaha², Deni K. \\ Sunjaya $^{2}$ \\ ${ }^{1}$ Program Studi Kesehatan Masyarakat STIKes Dharma Husada Bandung \\ ${ }^{2}$ Departemen Ilmu Kesehatan Masyarakat Fakultas Kedokteran Universitas Padjadjaran, \\ wenitusrini27@gmail.com
}

\begin{abstract}
Abstrak
Kepuasan pasien merupakan sarana penting untuk mengukur kualitas pelayanan kesehatan suatu penyedia pelayanan kesehatan. Waktu menunggu untuk sebuah pelayanan dianggap sebagai masalah serius dalam banyak sistem perawatan kesehatan karena merupakan hambatan untuk menciptakan pelayanan kepada pasien secara efektif dan efisien. Waktu pelayanan merupakan salah satu komponen yang potensial menyebabkan ketidakpuasan pada pasien di rumah sakit.. Tujuan penelitian yaitu untuk mengetahui gambaran waktu pelayanan dan waktu tunggu pendaftaran dan mengeksplorasi pelayanan pendaftaran di RSUD Kota Bandung melalui pendekatan aspek input dan aspek proses menggunakan teori Donabedian dan untuk mengetahui waktu mana yang berpotensi menyebabkan ketidakpuasan pada pasien serta menganalisis faktor penyebab ketidakpuasan terhadap waktu tunggu dan waktu pelayanan di pendaftaran di RSUD Kota Bandung. Penelitian ini menggunakan desain penelitian mixed methode dengan stategi embedded concurrent. Hasil penelitian menunjukkan waktu yang berpotensi menyebabkan ketidakpuasan pasien adalah waktu tunggu. Faktor penyebab lamanya waktu tunggu pelayanan adalah sosialisasi yang belum menyeluruh. Dari segi SDM untuk petugas masih kurang, baik di loket pendaftaran ataupun petugas SIM RS, sikap petugas masih kurang komunikatif, pemanfaatan teknologi berupa koneksi internet masih belum optimal.
\end{abstract}

Kata Kunci : Waktu Tunggu, Waktu Pelayanan, Donabedian

\section{PENDAHULUAN}

Saat ini kesadaran masyarakat akan kesehatan semakin meningkat. Seiring dengan peningkatan kesadaran tersebut akan mengakibatkan tuntutan peningkatan terhadap kualitas pelayanan kesehatan. ${ }^{1}$ Tingkat kepuasan penerima pelayanan merupakan ukuran keberhasilan penyelenggaraan pelayanan. ${ }^{2}$ Kualitas layanan harus dimulai dari kebutuhan pelanggan dan berakhir dengan kepuasan pelanggan serta persepsi positif terhadap kualitas layanan. ${ }^{1}$ Kepuasan pasien dinilai sangat penting untuk menentukan nasib penyedia layanan kesehatan dan sistem layanan kesehatan, oleh karena itu perlu dilakukan pengukuran secara berkala untuk meningkatkan kualitas pelayanan kesehatan. ${ }^{3}$

Upaya peningkatan kualitas pelayanan kesehatan adalah langkah terpenting untuk meningkatkan daya saing usaha pemerintah baik pusat maupun daerah di sektor kesehatan. ${ }^{4}$ Kepuasan masyarakat erat 
kaitannya dengan mutu pelayanan. Salah satu upaya untuk melakukan peningkatan pelayanan kesehatan adalah dengan melakukan pengukuran kepuasan pasien. Salah satu metode dalam pengukuran kepuasan pasien adalah survei kepuasan pelanggan. ${ }^{5,6}$ Beberapa penelitian di Indonesia mengenai kepuasan pasien melakukan survei kepuasan masyarakat dengan menggunakan Peraturan Menteri Pendayagunaan Aparatur Negara Nomor 14 tahun 2017, tentang Pedoman Penyusunan Survei Kepuasan Masyarakat Unit Penyelenggara Pelayanan publik. ${ }^{7,8}$ Salah satu unsur yang terdapat dalam Permenpan Nomor 14 tahun 2017 tersebut adalah waktu pelayanan. ${ }^{9}$ Waktu pelayanan menurut Permenpan No 14 Tahun 2017 adalah jangka waktu yang diperlukan untuk menyelesaikan seluruh proses pelayanan dari setiap jenis pelayanan. ${ }^{9}$

Rumah Sakit Umum Daerah (RSUD)

Kota Bandung merupakan rumah sakit milik pemerintah di Kota Bandung yang terus menerus berupaya meningkatkan kualitas pelayanan terhadap masyarakat kota Bandung dan sekitarnya. Dalam upaya meningkatkan kualitas pelayanan, sejak tahun 2017 setiap triwulan RSUD Kota Bandung melakukan survei kepuasan masyarakat dengan menggunakan Permenpan Nomor 14 tahun 2017 terhadap 10 unit pelayanan yang ada di RSUD Kota Bandung antara lain pendaftaran, instalasi rawat jalan, instalasi rawat inap, ruang bersalin dan perinatologi, instalasi laboratorium patologi klinik, instalasi rehabilitasi medik, instalasi gawat darurat, instalasi farmasi, instalasi radiologi dan kasir.

Berdasarkan hasil survei kepuasan masyarakat RSUD Kota Bandung tahun 20172018 didapatkan hasil bahwa selama 2 tahun berturut-turut waktu pelayanan selalu berada pada tiga unsur dengan nilai terendah yang harus ditingkatkan. ${ }^{10,11}$ Berdasarkan hasil data rekap survei kepuasan masyarakat per unit pada triwulan IV tahun 2018 dengan mengkategorikan waktu pelayanan cepat dan waktu pelayanan tidak cepat didapatkan hasil distribusi frekuensi yang menunjukkan bahwa lokasi dengan nilai tertinggi waktu pelayanan yang tidak cepat di RSUD Kota Bandung adalah pelayanan di instalasi laboratorium patologi klinik sebesar $54,6 \%$ dan pelayanan pendaftaran sebanyak $51,8 \%$.

Pendaftaran pasien merupakan sub jenis pelayanan front office yang merupakan ujung tombak pelayanan rawat jalan karena merupakan pelayanan pertama dan secara langsung berinteraksi dengan pasien maupun keluarga pasien sehingga dapat memberikan kesan kepada pasien terhadap mutu pelayanan rumah sakit secara umum. Apabila pelayanan yang diberikan di loket pendaftaran belum optimal, seperti terjadi antrian dan menimbulkan waktu tunggu yang lama kepada pasien, maka kondisi ini dapat memicu rendahnya kepuasan pasien. ${ }^{12}$ 
Waktu pelayanan adalah lamanya waktu dari ketika pasien memasuki rumah sakit baik itu waktu yang digunakan untuk pendaftaran pasien, janji temu dokter rutin, perawatan ruang gawat darurat, tes laboratorium / diagnostik, prosedur, menerima hasil dari berbagai tes, sampai pasien meninggalkan rumah sakit. ${ }^{13}$ sedangkan waktu pelayanan merupakan salah satu komponen yang potensial menyebabkan ketidakpuasan pada pasien di rumah sakit. ${ }^{14,15,16}$ Di beberapa rumah sakit waktu pelayanan yang lama merupakan masalah yang sering menimbulkan keluhan. ${ }^{17}$ Selain waktu pelayanan, waktu menunggu untuk sebuah pelayanan dianggap sebagai masalah serius dalam banyak sistem perawatan kesehatan karena merupakan hambatan untuk menciptakan pelayanan kepada pasien secara efektif dan efisien. ${ }^{13,18,19}$ Waktu tunggu pelayanan pasien merupakan salah satu indikator kepuasaan pasien dan mutu pelayanan rumah sakit ${ }^{20}$ dan salah satu indeks untuk mengevaluasi kualitas layanan di unit pelayanan rumah sakit. ${ }^{21}$

Waktu tunggu memiliki empat aspek: obyektif, subyektif, kognitif dan afektif: ${ }^{22}$

1) Waktu tunggu obyektif adalah waktu yang berlalu yang diukur dengan stopwatch oleh pelanggan sebelum dilayani

2) Waktu tunggu subyektif adalah estimasi waktu tunggu pelanggan. Dalam studi penelitian sebelumnya, aspek subjektif diukur dengan menggunakan waktu tunggu yang dirasakan. Tidak mengherankan, perkiraan waktu tergantung pada waktu berlalu yang diukur secara obyektif.

3) Aspek kognitif dari penantian adalah evaluasi konsumen tentang penantian dengan penilaian dapat diterima, masuk akal, dapat ditoleransi serta dianggap pendek versus panjang.

4) Aspek afektif dari menunggu terdiri dari respons emosional terhadap menunggu seperti iritasi, kebosanan, frustrasi, stres, kesenangan, kebahagiaan, dan lain-lain. Aspek-aspek positif dan kognitif ini membentuk penilaian atas penantian.

Menurut Donabedian, ada tiga pendekatan evaluasi (penilaian) dalam mutu diantaranya adalah aspek input/struktur, aspek proses dan aspek outcome. ${ }^{23}$ Dari uraian-uraian diatas, aspek outcome pada pelayanan pendaftaran dan pelayanan instalasi laboratorium patologi klinik berdasarkan hasil Survei Kepuasan Masyarakat menunjukkan adanya suatu masalah yaitu dirasakan waktu pelayanan di kedua lokasi tersebut lama. Mutu pelayanan kesehatan adalah hasil akhir (outcome) dari interaksi dan ketergantungan antara berbagai aspek, komponen atau unsur.

Sejak tahun 1966 Avedis Donabedian mengembangkan suatu kerangka evaluasi mutu pelayanan, yang terdiri dari struktur, proses dan outcome. Beberapa penelitian menggunakan metode ini untuk melakukan evaluasi suatu pelayanan kesehatan dalam 
metode ini menunjukkan bahwa seseorang dapat menilai apakah perawatan berkualitas tinggi disediakan dengan memeriksa struktur pengaturan di mana perawatan disediakan, dengan mengukur proses perawatan yang sebenarnya, dan/atau dengan menilai apa hasil perawatan. ${ }^{24,25,26,27}$ Dalam penelitian ini dilakukan analisis untuk mengetahui waktu yang berpotensi mengakibatkan ketidakpuasan pada pasien serta dilakukan penilaian mengenai kualitas pelayanan dari aspek input/struktur serta aspek proses untuk menganalisis faktor-faktor penyebab lamanya waktu tunggu dan atau waktu pelayanan di pendaftaran Rumah Sakit Umum Daerah Kota Bandung.

\section{METODE}

Penelitian ini menggunakan desain penelitian mixed methode dengan stategi embedded concurrent dimana penelitian kuantitatifnya ditancapkan pada penelitian kualitatif. Penelitian kuantitatif menggunakan pendekatan deskriptif untuk menggambarkan waktu pelayanan dan waktu tunggu pelayanan di pendaftaran RSUD Kota Bandung. Penelitian kualitatif menggunakan pendekatan studi kasus dengan paradigma interpretivisme untuk menggali informasi, dan pandangan informan mengenai kualitas aspek input/struktur dan aspek proses pelayanan pendaftaran. Teknik pengumpulan data dilakukan dengan data primer dan data sekunder. Data primer diperoleh melalui wawancara mendalam (indepth Interview) dan data sekunder diperoleh melalui studi dokumen data-data yang berhubungan dengan pelayanan pendaftaran.

\section{HASIL DAN PEMBAHASAN}

\section{A. HASIL}

\section{Tabel 1. Observasi Waktu Tunggu Pelayanan Pendaftaran RSUD Kota Bandung (n=61)}

\begin{tabular}{ll}
\hline Waktu Tunggu & Waktu Total \\
\hline Terpendek & 15 menit \\
Mean & 70.21 menit \\
Terlama & 126 menit \\
\hline
\end{tabular}

\begin{tabular}{lccc}
\hline Waktu & Waktu & Waktu & Waktu \\
Loket 1 & Loket 2 & Loket 3 & Loket 4 \\
\hline 45 menit & 52 menit & 15 menit & 27 menit \\
89,33 menit & 90,93 menit & 47,58 menit & 56,25 menit \\
120 menit & 126 menit & 81 menit & 80 menit \\
\hline
\end{tabular}

Keterangan :

Loket 1 : Loket poli jantung

Loket 2 : Loket poli penyakit dalam dan poli syaraf

Loket 3 : Loket rehabilitasi medik dan poli kandungan

Loket 4 : Loket Kasus Bedah

Tabel 1 menunjukkan bahwa waktu terpendek untuk waktu tunggu pelayanan di pendaftaran adalah 15 menit di loket 3 (loket rehabilitasi medik dan poli kandungan), dengan nilai rerata adalah 70,21 menit di loket 3 dan waktu terlama adalah 126 menit di loket 2 (loket poli penyakit dalam dan poli syaraf). Hasil data waktu pelayanan di pendaftaran dianalisis menggunakan SPSS versi 20 dan dilakukan uji normalitas data dihasilkan data tidak terdistribusi normal dengan nilai $\mathrm{p}=0,000$ sehingga digunakan nilai median. 
Tabel 2. Observasi Waktu Pelayanan Pendaftaran RSUD Kota Bandung $(\mathrm{n}=61)$

\begin{tabular}{lccccc}
\hline $\begin{array}{c}\text { Waktu } \\
\text { pelayanan }\end{array}$ & $\begin{array}{c}\text { Waktu } \\
\text { Total }\end{array}$ & $\begin{array}{c}\text { Waktu } \\
\text { Loket } \\
1\end{array}$ & $\begin{array}{c}\text { Waktu } \\
\text { Loket } \\
2\end{array}$ & $\begin{array}{c}\text { Waktu } \\
\text { Loket } \\
3\end{array}$ & $\begin{array}{c}\text { Waktu } \\
\text { Loket } \\
4\end{array}$ \\
\hline Terpendek & $2 \mathrm{mnt}$ & $2 \mathrm{mnt}$ & $2 \mathrm{mnt}$ & $3 \mathrm{mnt}$ & $3 \mathrm{mnt}$ \\
Median & $4 \mathrm{mnt}$ & $3 \mathrm{mnt}$ & $3 \mathrm{mnt}$ & $4 \mathrm{mnt}$ & $6 \mathrm{mnt}$ \\
Terlama & $8 \mathrm{mnt}$ & $5 \mathrm{mnt}$ & $7 \mathrm{mnt}$ & $8 \mathrm{mnt}$ & $8 \mathrm{mnt}$ \\
\hline
\end{tabular}

Keterangan :

Loket 1 : Loket poli jantung

Loket 2 : Loket poli penyakit dalam dan poli syaraf

Loket 3 : Loket rehabilitasi medik dan poli kandungan

Loket 4 : Loket Kasus Bedah

Tabel 2 menunjukkan waktu terpendek untuk waktu pelayanan di pendaftaran adalah 2 menit di loket 1 (loket poli jantung), dengan nilai median/nilai tengah adalah 4 menit di loket 3 dan waktu terlama adalah 8 menit di loket 3 (loket rehabilitasi medik dan poli kandungan).

Berdasarkan hasil observasi dan dibandingkan dengan hasil survei kepuasan masyarakat yang menunjukkan hasil dimana unsur waktu pelayanan bernilai rendah di pendaftaran yang berarti termasuk waktu pelayanan yang tidak cepat maka peneliti berasumsi bahwa yang dimaksud waktu pelayanan yang lama menurut persepsi pasien adalah waktu tunggu.Waktu tunggu yang merupakan jeda waktu dimana pasien mengambil nomor antrian sampai pasien dilayani oleh petugas pendaftaran yang ratarata sekitar 70 menit pasien harus menunggu sebelum dilayani oleh petugas pendaftaran, karena jika dilihat dari waktu pelayanan pendaftaran sudah tergolong cepat dimana waktu pelayanan hanya sekitar 4 menit.

Jurnal Penelitian Kesehatan STIKes Dharma Husada Bandung
Berdasarkan hasil kualitatif pada 3 (tiga) orang informan dan observasi mengenai aspek input/struktur dan aspek proses pada pelayanan pendaftaran di RSUD Kota Bandung, maka ditemukan faktor-faktor penyebab lamanya waktu tunggu di pendaftaran sebagai berikut :

1) Kapasitas petugas

a) Jumlah petugas

Hasil wawancara 2 (orang) informan mengutarakan bahwa jumlah petugas di pendaftaran ini tidak mencukupi untuk melaksanakan pelayanan di pendaftaran agar lebih cepat. Keterbatasan petugas menjadi salah satu penyebab lamanya pelayanan di pendaftaran.

b) Komunikasi

Diperlukan sikap petugas yang baik dan bisa menyampaikan informasi mengenai segala hal yang berkaitan dengan pelayanan di rumah sakit. Sikap tersebut sangat diperlukan agar tidak terjadi kesenjangan informasi antara pihak rumah sakit dan pasien atau keluarga pasien yang akan mendaftar.

\section{2) Faktor Pasien}

a) Usia

Hasil penelitian menunjukkan bahwa ratarata usia pasien yang berkunjung ke RSUD Kota Bandung adalah usia 40 Tahun ke atas sehingga hal tersebut menyebabkan pasien sulit mengerti mengenai layanan sistem pengambilan antrian online yang telah disediakan oleh pihak rumah sakit untuk mengurangi waktu tunggu di pendaftaran. 
b) Apatis

Berbagai perubahan untuk membuat pelayanan semakin efektif dan efisien ternyata tidak dimanfaatkan oleh seluruh pasien di Rumah Sakit, bukan karena tidak mampu tetapi tidak mau karena terbiasa dan merasa nyaman dengan sistem yang manual (tradisional).

c) Kondisi ekonomi

Hasil penelitian menunjukkan bahwa ratarata usia pasien yang berkunjung ke RSUD Kota Bandung adalah kondisi ekonomi menengah ke bawah, sehingga untuk menggunakan sistem pengambilan antrian online yang menggunakan alat bantu seperti Handphone dirasa memberatkan bagi sebagian pasien dan keluarga pasien sehingga mereka lebih memilih sistem manual (tradisional).

\section{3) Sarana Prasarana}

a) Posisi Banner

Posisi Banner di pendaftaran terlalu kecil dan hanya satu buah sehingga tidak memberikan banyak informasi bagi pengunjung yang datang ke rumah sakit.

b) Fungsi LCD

LCD yang tersedia di ruang pendaftaran tidak dimanfaatkan dengan baik, hal ini dilihat dari kondisi LCD yang mati dan tidak berfungsi dengan baik.

4) Teknologi

a) Kekuatan Koneksi

Jumlah server menentukan kekuatan koneksi dalam suatu tempat, jumlah server di RSUD Kota Bandung masih dirasakan kurang untuk memenuhi kebutuhan pada proses pelayanan

b) Gangguan Koneksi

$\begin{array}{clcc}\text { Hasil wawancara dengan beberapa } & \text { anguan }\end{array}$
koneksi sangat mengganggu jalannya proses pelayanan, Gangguan koneksi ini sering terjadi sehingga menghambat proses pelayanan di unit pendaftaran karena untuk kegiatan proses pelayanan di unit pendaftaran memerlukan koneksi internet yang baik.

c) Kerusakan Jaringan

Dalam proses pelayanan pendaftaran sudah bersifat online dan terhubung dengan provider yang berhubungan dengan pasien dalam hal ini provider yang mendominasi pada pelayanan di RSUD Kota Bandung adalah BPJS. Namun kerusakan sering terjadi yang diakibatkan oleh kerusakan jaringan yang berasal dari provider itu sendiri dan jika hal tersebut terjadi pihak RSUD Kota Bandung tidak bisa berbuat apaapa hanya menunggu sampai jaringan kembali normal.

\section{5) Sistem Informasi Manajemen RS}

a) Jumlah Petugas SIM RS

Peran Sistem Informasi Manajemen Rumah Sakit (SIM RS) sangat penting dalam rangka peningkatan pelayanan pada pasien terus dikembangkan di RSUD Kota Bandung, namun sering terjadi kendala dalam pengoperasiannya dikarenakan SIM RS ini bersifat terintegrasi maka jika aplikasi atau SIM RS sedang ada masalah penanganannya agak terlambat karena keterbatasan petugas SIM RSnya. 
b) Gangguan Aplikasi

Dari hasil wawancara dengan beberapa informan, bahwa adanya gangguan aplikasi sering menghambat proses pelayanan.

c) Respon Petugas

Dari hasil wawancara dengan beberapa informan menyatakan bahwa respon dari petugas tim SIM RS kurang, sehingga penanganan akan adanya kerusakan yang terjadi di unit pendaftaran tidak dapat dilakukan secepatnya.

6) Kesenjangan Informasi

a) Media Informasi tentang Pelayanan

Terbatasnya media informasi mengenai pelayanan khususnya pelayanan pendaftaran menyebabkan kesenjangan informasi antara pihak rumah sakit dan pasien

b) Informasi mengenai Metode SMS

Informasi mengenai metode sistem antrian bagi pasien lama tidak dapat dioptimalkan dikarenakan belum semua pasien memahami bagaimana caranya bahkan ada yang tidak mengetahui informasi tersebut.

\section{B. PEMBAHASAN}

\section{1) Penelitian Kuantitatif}

Hasil penelitian kuantitatif berupa gambaran mengenai watu tunggu dan waktu pelayanan di pendaftaran. Berdasarkan hasil observasi yang dilakukan oleh peneliti mengenai waktu tersebut, waktu yang berpotensi memberikan kontribusi terhadap rendahnya nilai unsur waktu pelayanan menurut kuesioner Survei Kepuasan Masyarakat dengan menggunakan Permenpan Nomor 14 Tahun 2017 di pendaftaran adalah waktu tunggu pelayanan, yang dimaksud dengan waktu tunggu pelayanan ini adalah jeda waktu dimana pasien mengambil nomor antrian sampai dengan pasien dipanggil di loket pendaftaran untuk dilayani oleh petugas pendaftaran. Hasil observasi menunjukkan waktu tunggu rerata di pendaftaran adalah 70,21 menit dan loket yang memiliki waktu tunggu terlama adalah loket poli penyakit dalam dan poli penyakit jantung. Hal ini sesuai dengan data kunjungan pasien rawat jalan dimana pasien rawat jalan terbanyak mengunjungi poli dalam, disusul oleh poli rehabilitasi medik lalu poli syaraf selanjutnya adalah poli jantung. Jadi dapat disimpulkan bahwa jumlah kunjungan pasien rawat jalan yang tinggi pada poli tertentu menjadi salah satu faktor yang mempengaruhi lamanya waktu tunggu pelayanan. Waktu tunggu dalam aspek subjektif dimana pasien mengukur waktu pelayanan berdasarkan waktu tunggu yang dirasakan oleh pasien secara objektif serta aspek afektif dimana pasien mengevaluasi dari penantian yang pasien rasakan, ${ }^{28}$ berdasarkan hasil observasi yang dilakukan oleh peneliti waktu tunggu pasien pada tahap tersebut waktu terlama pasien menunggu dari mengambil antrian sampai dipanggil menuju loket antrian adalah 126 menit dan waktu tercepatnya adalah 15 menit. 
Sementara waktu tunggu pada tahap tersebut tidak tercantum dalam Standar Pelayanan Minimal (SPM) yang ditentukan oleh Kepmenkes maupun Standar Operasional Prosedur Rumah Sakit.

Berdasarkan hasil wawancara terlihat ada beberapa perbaikan yang dilakukan untuk mengurangi waktu tunggu diantaranya adalah :

a) Model penerimaan sebelum penerimaan pasien

Pada model ini diterapkan sistem reservasi dimana di RSUD Kota Bandung reservasi yang digunakan adalah melalui Short Message Service (SMS) atau pesan singkat. Dengan menggunakan model ini dapat memangkas waktu tunggu pasien karena pasien tidak harus menunggu lama di ruang pendaftaran. ${ }^{29,30} \mathrm{Di}$ RSUD Kota Bandung pasien lama yang akan berobat jalan dapat mendaftarkan melalui SMS ke nomor hotline service khusus untuk pendaftaran rawat jalan. Pendaftaran SMS dimulai pukul 4.00 WIB dan pasien akan mendapatkan balasan dari operator RSUD Kota Bandung untuk mendapatkan estimasi kedatangan waktu pendaftaran setelah itu pasien melakukan verifikasi (pengambilan SEP bagi pasien BPJS) dilakukan di loket pendaftran sesuai nomor antrian yang ada pada balasan SMS.

b) Disiplin Antrian Priority Service (PS)

Priority Service adalah salah satu jenis disiplin antrian dimana prioritas pelayanan diberikan kepada prioritas yang lebih tinggi dibandingkan dengan pelanggan dengan pelanggan dengan prioritas lebih rendah. Pada disiplin antrian ini, seorang pasien dapat mendahului pasien di depannya yang sudah mengantri karena memiliki prioritas tertentu. ${ }^{31}$ Penelitian Nur Indra dan Nikenasih menunjukkan bahwa sistem antrian priority service dapat meningkatkan keefektifan dalam pelayanan, ${ }^{32}$ hal yang sama ditunjukkan oleh Kailash dalam penelitiannya. ${ }^{33}$ RSUD Kota Bandung telah menerapkan Sistem Antrian Priority Service dimana prioritas diberikan kepada pasien geriatri, yang dimaksud dengan pasien geriatri adalah pasien dengan umur diatas 60 tahun dengan keluhan dua penyakit dan pasien diatas umur 70 tahun atau 80 tahun yang telah lapor sebagai pasien geriatri.

c) Model Sistem Antrian

Loket antrian di RSUD Kota Bandung terbagi menjadi 3 lokasi yaitu lantai 1 yang terdiri dari 4 loket yaitu loket 1 poli jantung, loket 2 poli dalam dan syaraf, loket 3 poli rehabilitasi medik dan kandungan, loket 4 semua kasus bedah, loket 5 di lantai 2 untuk poli anak, kulit, THT, dan mata dan loket 6 gedung belakang yang terdiri dari 1 loket khusus kasus gigi. Pengaturan loket secara grouping ini dilakukan untuk mengurangi waktu tunggu di pendaftaran pada pasien untuk poli-poli tertentu dan untuk pasien post rawat inap. Berdasarkan hasil observasi dengan pengaturan loket secara grouping dapat mengurangi waktu pelayanan terutama 
bagi poli yang sedikit angka kunjungannya, namun karena masih adanya kesenjangan informasi yang tersedia mengenai hal ini bagi pasien baru merasa heran karena nomor antrian yang lebih lama bisa dilayani terlebih dahulu sehingga menimbulkan pertanyaan.

Beberapa metode di atas diterapkan oleh RSUD Kota Bandung dalam upaya mempercepat waktu pelayanan, meskipun waktu pelayanan pendaftaran di RSUD Kota Bandung sudah mencapai standar pelayanan minimal namun pihak manajemen rumah sakit harus bisa lebih meningkatkan pelayanan dan mengantisipasi agar waktu pelayanan pendaftaran tetap memenuhi standar.

\section{2) Penelitian Kualitatif}

Berikut ini tema-tema/faktor-faktor yang dapat menyebabkan lamanya waktu tunggu pendaftaran di RSUD Kota Bandung berdasarkan hasil wawancara dan observasi yang dilakukan oleh peneliti:

\section{a) Kapasitas Petugas}

Keberadaan sumber daya manusia di dalam perusahaan mempunyai peran penting dalam mencapai tujuan organisasi. Kinerja karyawan mempengaruhi kepuasan pasien artinya jika kinerja karyawan baik maka pasien akan merasa puas. $^{34}$ Sementara salah satu faktor yang berpengaruh terhadap kinerja karyawan adalah keterampilan, dan pendidikan. Di RSUD Kota Bandung terdapat salah seorang petugas yang masa kerjanya baru satu tahun, hal ini dapat menyebabkan lamanya waktu pelayanan karena dengan masa kerja yang baru maka kemampuan dan keahlian dalam melakukan pekerjaan masih kurang. Selain itu juga terdapat salah seorang petugas dengan tingkat pendidikan Sekolah Menengah Atas (SMA) yang telah dibekali pelatihan oleh pihak RSUD Kota Bandung untuk dapat meningkatkan kemampuan dan keterampilannya. Pelatihan harus terus dijalankan karena banyak sekali kegiatan di pendaftaran ini yang berkaitan dengan keterampilan yang harus dimiliki oleh petugas pendaftaran. Masa kerja secara tidak langsung ikut memengaruhi waktu pelayanan pasien. Masa kerja berhubungan dengan pengalaman. Pengalaman merupakan suatu cara untuk memperoleh kebenaran pengetahuan dalam upaya meningkatkan pelayanan kepada pasien. ${ }^{15}$

Sikap petugas yang kurang komunikatif dapat menghambat waktu pelayanan karena jika petugas kurang komunikatif kepada pasien akan terjadi kesenjangan komunikasi dimana pesan yang disampaikan oleh petugas kurang dipahami oleh pasien. ${ }^{6}$ Kesenjangan informasi mengenai pelayanan di RSUD Kota Bandung menyebabkan pelayanan menjadi lama karena informasi yang disampaikan oleh petugas tidak dimengerti oleh pasien. Komunikasi merupakan faktor yang penting, sebab jika terjadi kesenjangan dalam komunikasi maka akan timbul penilaian dan 
persepsi yang negatif terhadap kualitas pelayanan seluruhnya. ${ }^{6}$ Selain itu beberapa hal tersebut berdasarkan hasil wawancara didapat pula faktor yang menyebabkan lama waktu pelayanan dimana sikap apatis dari para pengguna aplikasi yang disediakan oleh pihak rumah sakit bahwa tidak semua petugas kesehatan di RSUD Kota Bandung memanfaatkan aplikasi ini dengan baik. Beberapa petugas kesehatan menggunakan sistem manual karena alasan sudah terbiasa dengan penggunaan sistem manual dibandingkan dengan menggunakan aplikasi.

Berdasarkan hasil wawancara beberapa informan mengatakan bahwa jumlah sumber daya manusia kurang, hal ini dikarenakan terdapat beberapa petugas pendaftaran berhenti bekerja dan sampai saat ini belum ada yang menggantikan posisi yang ditinggalkan oleh petugas yang berhenti bekerja sehingga petugas yang lain harus mengisi tugas untuk posisi yang ditinggalkan. Menurut penelitian Elmira Febri, ${ }^{35}$ hal demikian memiliki pengaruh yang siginifikan terhadap output kinerja yang dihasilkan. Beban kerja yang banyak pada karyawan dapat mengakibatkan produktivitas yang dihasilkan menjadi kurang fokus dan kurang efektif, bahkan pelayanan terhadap pasien pun dapat menurun. Permasalahan lain yang terjadi pada loket pelayanan pendaftaran ini adalah karakter pasien yang mengantri untuk mendapatkan pelayanan.
Berdasarkan hasil wawancara dengan informan, kadang-kadang ada pasien yang keras kepala ketika diberikan penjelasan mengenai persyaratan yang seharusnya dipenuhi oleh pasien namun pasien tersebut tidak mau terima dan akhirnya marah-marah tentunya hal ini dapat menghambat pelayanan pada pasien lain dan menyebabkan pelayanan menjadi lama. Hal ini sejalan dengan penelitian yang dilakukan oleh Ade Selvia, dkk yang menyatakan bahwa perilaku pasien merupakan salah satu faktor yang menyebabkan lamanya waktu pelayanan. ${ }^{12}$

Selain itu berdasarkan hasil wawancara dengan informan menyatakan bahwa usia dan kondisi ekonomi menjadi salah satu faktor penyebab lamanya waktu pelayanan karena rata-rata usia pasien yang datang ke RSUD Kota Bandung di atas 40 tahun sehingga tidak dapat menggunakan fasilitas yang diberikan oleh RSUD Kota Bandung seperti fasilitas pendaftaran SMS dikarenakan tidak paham menggunaan telepon genggam atau untuk pasien dengan kondisi ekonomi kebanyakan menengah ke bawah yang tidak memiliki alat komunikasi atau tidak terbiasa menggunakan alat komunikasi. Mereka lebih memilih untuk datang langsung mengambil antrian daripada mendaftarkan lewat SMS. Jumlah kunjungan di RSUD Kota Bandung tergolong cukup tinggi dengan angka kunjungan terbanyak 400 pasien dalam sehari. Tingginya tingkat kunjungan pasien di RSUD Kota Bandung 
merupakan salah satu faktor penyebab lamanya waktu tunggu di RSUD Kota Bandung. ${ }^{36}$

b) Alat penunjang

Sarana prasarana/alat penunjang adalah salah satu faktor penting dalam suatu pelayanan, berdasarkan hasil wawancara keterbatasan alat dan kerusakan alat dapat menyebabkan lamanya waktu pelayanan pendaftaran. Berdasarkan hasil observasi posisi banner tidak strategis sehingga tidak dapat dibaca oleh pasien dan juga tatacara pengambilan antrian melalui SMS hanya berada di dekat mesin antrian begitu juga dengan LCD yang dibiarkan mati dan tidak dimanfaatkan apa-apa alangkah lebih baik jika LCD tersebut bisa digunakan sebagai salah satu media informasi dengan menampilkan informasi-informasi mengenai persyaratan pendaftaran atau informasi-informasi lain yang berkaitan dengan proses pelayanan di RSUD Kota Bandung.

\section{c) Teknologi}

Dalam era globalisasi seperti saat ini perkembangan ilmu pengetahuan yang pesat diikuti oleh teknologi informasi. Melalui teknologi informasi seseorang dapat memperoleh informasi dengan cepat dan mudah. Salah satu produk teknologi yang digunakan dalam bidang kesehatan adalah internet. ${ }^{37}$ Sama halnya dalam dunia pekerjaan, internet sangat berperan penting untuk melakukan suatu pelayanan. Salah satu manfaat internet adalah mempercepat proses pelayanan, namun untuk dapat bisa dimanfaatkan secara optimal internet memerlukan dukungan jaringan yang baik. Berdasarkan hasil wawancara hampir dengan seluruh informan menyatakan kekuatan koneksi dan gangguan koneksi menjadi salah satu faktor penyebab lamanya waktu pelayanan pendaftaran, server yang terbatas menghambat proses pelayanan di pendaftaran karena dengan server yang terbatas kekuatan koneksi internet menjadi lambat selain itu gangguan koneksi sering terjadi di unit pendaftaran RSUD Kota Bandung. Hal ini sejalan dengan beberapa penelitian yang menyebutkan gangguan koneksi internet sebagai faktor yang memengaruhi lamanya waktu pelayanan. ${ }^{15}$

d) Sistem Informasi Manajemen Rumah Sakit (SIM RS)

Hasil penelitian di RSUD Kota Bandung menunjukkan bahwa Sistem Informasi Manajemen Rumah Sakit (SIM RS) memiliki peranan penting bagi proses pelayanan di pendaftaran. Namun terdapat beberapa kendala yang dapat menghambat kecepatan pelayanan, berdasarkan hasil wawancara faktor-faktor tersebut adalah gangguan jaringan internal yang terjadi di RSUD Kota Bandung terkadang aplikasi SIM RS tidak terkoneksi sehingga harus restart ulang program yang tentunya menyita waktu, selain itu jika ada gangguan jaringan dikarenakan 
jumlah petugas SIM RS yang terbatas sehingga mengakibatkan tanggapan dan penanganannya lama bahkan pernah petugas SIM RS tidak memberikan tanggapan atas keluhan yang dilontarkan oleh petugas pendaftaran dan ketika dilaporkan kepada kepala unit rekam medis baru mendapat tanggapan. Hal ini sejalan dengan penelitian yang dilakukan oleh Aniza Ismail dkk yang menunjukkan bahwa sumber daya manusia yang berkualitas, sistem pendukung yang baik, ramah pengguna dan pelatihan yang memadai dari pengguna akhir akan menentukan keberhasilan implementasi Sistem Informasi Manajemen Rumah Sakit (SIM RS). ${ }^{38}$

\section{e) Informasi}

Permasalahan yang sering muncul berdasarkan hasil wawancara dengan informan adalah beberapa pasien masih belum mengetahui informasi persyaratan untuk melakukan pendaftaran, terutama untuk pasien baru seringkali tidak membawa persyaratan yang diperlukan pada saat melakukan proses pendaftaran dan untuk pasien lama tidak memperhatikan waktu yang sudah ditentukan oleh pihak provider. Berdasarkan penelitian, masih ditemui beberapa pasien yang belum melengkapi berkas persyaratan pendaftaran ketika sudah mendapat panggilan menuju loket tujuan, sehingga waktu tunggu kepada pasien berikutnya menjadi berlangsung lama. Keadaan ini umumnya terjadi pada pasien peserta BPJS. Persyaratan merupakan salah satu unsur dari 9 unsur yang merupakan fokus dalam pelaksanaan Survei Kepuasan Masyarakat. Selain persyaratan, prosedur merupakan salah satu unsur juga yang terdapat pada 9 unsur penilaian tersebut, bahkan untuk prosedurpun berada pada 3 unsur dengan nilai terendah artinya ada potensi ketidakpuasan masyarakat terhadap prosedur yang ada. Oleh karena itu informasi yang sejelas-jelasnya sangat dibutuhkan oleh pasien. Menurut penelitian yang dilakukan oleh Sulistiyorini dalam Bustani, ${ }^{15}$ ketidaksiapan pasien membawa berkas persyaratan pendaftaran pasien rawat jalan juga menjadi faktor penyebab lamanya waktu tunggu pelayanan. Hal serupa juga diungkapkan dalam penelitian Febriyanti dalam Bustani, ${ }^{15}$ bahwa persyaratan pasien yang belum lengkap ini masuk dalam 10 faktor yang mempengaruhi lamanya waktu tunggu pelayanan.

Keterbatasan media informasi juga menyebabkan informasi mengenai persyaratan kurang dipahami oleh pasien, ketersediaan informasi yang ada hanya berupa banner informasi tentang alur pendaftaran dan tersedia hanya di dekat mesin antrian saja. Sebaiknya banner dibuat lebih menarik agar pasien merasa tertarik membaca banner tersebut sehingga informasi yang disampaikan dapat diterima oleh pasien. Keadaan ini juga menggambarkan adanya kesenjangan komunikasi oleh rumah sakit kepada pasien, di mana rumah sakit kurang dapat menyajikan informasi yang banyak kepada pasien. 


\section{KESIMPULAN}

Gambaran mengenai waktu tunggu adalah sebagai berikut : Waktu terpendek untuk waktu tunggu pelayanan di pendaftaran adalah 15 menit di loket 3 (loket rehabilitasi medik dan poli kandungan), dengan nilai rerata adalah 70,21 menit di loket 3 dan waktu terlama adalah 126 menit di loket 2 (loket poli penyakit dalam dan poli syaraf).

Gambaran mengenai dan waktu pelayanan pendaftaran : Waktu terpendek untuk waktu pelayanan di pendaftaran adalah 2 menit di loket 1 (loket poli jantung), dengan nilai median/nilai tengah adalah 4 menit di loket 3 dan waktu terlama adalah 8 menit di loket 3 (loket rehabilitasi medik dan poli kandungan). optimal untuk membantu proses pelayanan pendaftaran, kondisi pasien yang berkunjung diatas 40 tahun dan kondisi ekonomi di kelas bawah, teknologi yang ada masih belum maksimal seperti sering terjadi gangguan jaringan dan koneksi internet yang kurang kuat, SIM RS sudah berjalan namun jumlah petugas masih kurang hanya 2 orang teknisi dan 2 orang programmer. Faktor penyebab lamanya waktu tunggu pendaftaran adalah sosialisasi yang belum menyeluruh, dari segi SDM untuk petugas masih kurang, baik di loket pendaftaran ataupun petugas SIM RS, sikap petugas masih kurang komunikatif, pemanfaatan teknologi berupa koneksi internet masih belum optimal.

Waktu yang berpotensi menyebabkan ketidakpuasan pasien pada pendaftaran adalah waktu tunggu. Hasil pemaparan gambaran Jurnal Penelitian Kesehatan STIKes Dharma Husada Bandung aspek input/struktrur dan aspek proses pada pelayanan pendaftaran : Secara Kuantitas petugas pendaftaran masih kurang, namun secara kualitas sudah cukup memadai, sarana prasarana yang ada belum dimanfaatkan secara

\section{REFERENSI}

1. Supriyanto Yuda, Soesanto Harry. Analisis Pengaruh Kualitas Pelayanan, Harga, dan Fasilitas terhadap Kepuasan Pasien Rawat Jalan Di Rumah Sakit Kariadi Semarang. Diponegoro Journal of Management. 2012;1(1):472-480.

2. Al-Abri Rashid, Al Balushi Amina. Patient Satisfaction Survey as Tool Towards Quality Improvement. Oman Medical Journal. 2014;29(1);3-7.

3. Munijaya, I Gde. Manajemen Mutu Pelayanan Kesehatan. Penerbit Buku Kedokteran, EGC: Jakarta. 2011.

4. Surosa, Jebul. Indeks Kepuasan Pasien Suatu Rumah Sakit Swasta di Purwokerto. Purwokerto. 2011.

5. Subedi D, Uprety K. Patients' Satisfaction With Hospital Services In Kathmandu. Journal of Chitwan Medical College. 2014;4(9):25-31.

6. Tjiptono, F., \& Chandra, G. Service, Quality, \& Satisfaction. Edisi Ketiga. Penerbit Andi: Yogyakarta. 2011.

7. Siswati Sri, Ambiyar. Pengaruh Pelayanan dan Sarana Pengaduan Terhadap Survey Kepuasan Masyarakat di Poli Bedah RSUP DR. M. JAMIL Padang Tahun 2018. Jurnal Seminastika. Balikpapan. 2018:286-290.

8. Siswati Sri, Ernawati Tuti CH. Kontribusi Informasi Hak dan Kewajiban Pasien dengan Indeks Kepuasan Masyarakat di Poli Bedah RSUP DR. M. JAMIL Padang dari Sisi Penjelasan Tenaga Kesehatan Tentang Hak Pasien Tahun 2018. Jurnal Seminastika. Balikpapan. 2018:294-297. 
9. Menteri Pendayagunaan Aparatur Negara. Permenpan Nomor 14 tahun 2017 Tentang Pedoman Penyusunan Survey Kepuasan Masyarakat Unit Penyelenggara Pelayanan Publik. 2017.

10.Laporan Survey Indeks Kepuasan Masyarakat (IKM) RSUD Kota Bandung Tahun 2017.

11.Laporan Survey Indeks Kepuasan Masyarakat (IKM) RSUD Kota Bandung Tahun 2018.

12.Septiani Ade Selvia, Wigati Putri Asmita, Fatmasari Eka Yunila. Gambaran Sistem Antrian Pasien Dalam Optimasi Pelayanan di Loket Pendaftaran Instalasi Rawat Jalan Rumah Sakit Umum Pusat Fatmawati. 2017;5(4):1-14.

13.T.A Dinesh, et.al. Reducing Waiting Time in Outpatient Services of Large University Teaching Hospital-A Six Sigma Approach. Management In Health. 2013;17(1).

14.Sriram Shyamkumar, Noochpoung Rakchanok. Determinants of hospital waiting time for outpatient care in India: how demographic characteristics, hospital ownership, and ambulance arrival affect waiting time. International Journal of Community Medicine and Public Health. 2018;5(7):2692-2698.

15.M. Bustani Neti, Rattu A. Joy, Saerang Josephine S. M. Analisis Lama Waktu Tunggu Pelayanan Pasien Rawat Jalan di Balai Kesehatan Mata Mayarakat Propinsi Sulawesi Utara. Jurnal e-Biomedik (eBm). 2015;3(3):872-883.

16.Laeliyah Nur, Subekti Heru. Waktu Tunggu Pelayanan Rawat Jalan dengan Kepuasan Pasien Terhadap Pelayanan di Rawat Jalan RSUD Kabupaten Indramayu. Jurnal Kesehatan Vokasional. 2017;1(2):102-112.
17.Rissa Pratiwi Muthiah, Nasrul Sani Fakhrudin. Hubungan Waktu Tunggu Pelayanan Terhadap Tingkat Kepuasan Pasien di Poliklinik Kebidanan dan Kandungan RSUD Kota Surakarta. Profesi. 2017;14(2): 24-31.

18. Yusri Muhammad. Analisis Faktor yang Berhubungan dengan Waktu Tunggu Pemeriksaan Foto Toraks Pasien Rawat Jalan di Instalasi Radiologi Rumah Sakit Dr. Mohammad Hoesin Palembang Tahun 2015. Jurnal Administrasi Rumah Sakit. 2015;2(1):64-71

19.Pianykh OS, Rosenthal DI. Can We Predict Patient Wait Time ?. Journal American College of Radiology. 2015;12(10):10581066.

20.Torry, Koeswo Mulyatim, Sujianto. Faktor yang Mempengaruhi Waktu Tunggu Pelayanan Kesehatan Kaitannya dengan Kepuasan Pasien Rawat Jalan Klinik Penyakit Dalam RSUD Dr. Iskak Tulungagung. Jurnal Kedokteran Brawijaya . 2016;29(3):252-257.

21.Khursheed Munawar, et.al. Real-Time Patient Satisfaction of Emergency Department Services in a Tertiary Care Hospital in Karachi, Pakistan. Emergency Medicine: Open Access. 2014;4(3):1-6.

22.Chandra Disha. Reducing Waiting Time of Outdoor Patients in Hospitals Using Different Types of Models: A Systematic Survey. International Journal of Business and Management Review. 2017;4(1):79-91.

23.Rahmawati, Ellief Fariha, Pudjirahardjo, Widodo J. Analisis Kepuasan Pasien Terhadap Kualitas Pelayanan dengan Teori Donabedian di Instalasi Laboratorium. Jurnal Administrasi Kesehatan Indonesia;20142(1):67-74.

24.Menteri Kesehatan. Peraturan Menteri Kesehatan Republik Indonesia No. 56 Tahun 2014 tentang Klasifikasi dan Perizinan Rumah Sakit. 2014. 
25.Sardasht, Fatemeh Ghaffari, et.al. Application of Donabedian Quality-of-Care Framework to Assess the Outcomes of Preconception Care in Urban Health Centers, Mashhad, Iran in 2012. Journal of Midwifery \& Reproductive Health. 2013; 1(2):50-59.

26.El Haj Hanae Ibn, Lamrini Mohamed, Rais Noureddine. Quality of Care Between Donabedian Model and ISO9001V2008. International Journal for Quality Research. 2013;7(1):17-30.

27.Moore Lynne, et.al. Donabedian's structure-process-outcome quality of care model: Validation in an integrated trauma system. Journal of Trauma and Acute Care Surgery. 2015;78(6):1168-1175.

28. Bielen Frederic. Waiting time influence on the satisfaction-loyalty relationship in services. Managing Service Quality. 2017;17(22):174-193.

29. Wankar Abhinav Dileep. Study of Determination of Laboratory Turnaround Time in Tertiary Care Hospital in India. International Journal of Research in Medical Sciences. 2014;2(4):1396-1401.

30.Mohebbifar Rafat, et.al. Outpatient Waiting Time in Health Services and Teaching Hospitals: A Case Study in Iran. Global Journal of Health Science. 2014;6(1):172180.

31.Aditama Tommy Yoga, Wardhani Laksmi Prita. Distribusi Waktu Tunggu Pada Antrian Dengan Menggunakan Disiplin Pelayanan Prioritas (Studi Kasus: Instalasi Rawat Darurat Di RSUD Dr. Soetomo Surabaya). Jurnal Sains dan Seni POMITS. 2013;1(1):1-6.
32.Istiani Nur Indra, Binatari Nikenasih. Analisis Sistem Antrean dengan Disiplin Pelayanan Preemptive. Jurnal Sains Dasar. 2017;6(2).

33.Kailash, C. A Non-Preemptive Priority Queueing System with a Single Server Serving Two Queues M/G/1 and M/D/1 with Optional Server Vacations Based on Exhaustive Service of the Priority Units. Academic Journal. 2011;26 (1): 14-17.

34.Amelia Riski, Dra Rodhiyah S.U. Pengaruh Kualitas Pelayanan Dan Kinerja Karyawan Terhadap Kepuasan Pasien (Studi Kasus Pada Pasien Rawat Inap RS.Pelabuhan Jakarta). Jurnal Ilmu Administrasi Bisnis. 2016;5(4).

35.Darmayanti, Elmira Febri. Analisis Produktivitas Kerja Karyawan Dikaitkan dengan Time Management. Jurnal AKUISISI Univ Muhammadiyah Metro Lampung. 2016;12.

36.Fuanasari, Ayu Diana. Analisis Alur Pelayanan dan Antrian di Loket Pendaftaran Pasien Rawat Jalan RSUD Kota Semarang. Skripsi Sarjana Fakultas Kesehatan Masyarakat Universitas Diponegoro Semarang. 2013.

37. Yani Ahmad. Pemanfaatan Teknologi Dalam Bidang Kesehatan Masyarakat. Jurnal Kesehatan Masyarakat. 2018;8(1):97-102.

38.Ismail Aniza, et al. The Implementation of Hospital Information System (HIS) in Tertiary Hospitals in Malaysia: A Qualitative Study. Malaysian Journal of Public Health Medicine. 2010;10(2):16-24. 